\title{
ANALISIS SEKTOR PARIWISATA TERHADAP PENDAPATAN ASLI DAERAH (PAD) (Studi Empiris Pada Daerah Istimewa Yogyakarta Tahun 2012-2018)
}

\author{
Dita Novita Dewi ${ }^{1}$, Suyatmin Waskito $\mathrm{Adi}^{2}$ \\ Faculty of Business Economics Muhammadiyah Surakarta University \\ b200170273@student.ums.ac.id
}

\begin{abstract}
Abstrak: Pendapatan Asli Daerah merupakan salah satu indikator dari kemandirian otonomi daerah dalam menggali potensi untuk meningkatkan sumber-sumber penerimaan. Penelitian ini bertujuan untuk menganalisis pengaruh jumlah wisatawan, jumlah obyek wisata dan jumlah hotel terhadap pendapatan asli daerah. Penelitian ini menggunakan metode regresi data panel yaitu metode gabungan dari data time series dan data cross section. Populasi dalam penelitian ini adalah 5 kota/kabupaten di Daerah Istimewa Yogyakarta tahun 2012-2018. Teknik pengambilan sampel dalam penelitian ini menggunakan metode purposive sampling, kemudian diperoleh sampel sebanyak 35 . Jenis data yang digunakan adalah data sekunder dengan metode dokumenter yang dipublikasi oleh Badan Pusat Statistik Provinsi Daerah Istimewa Yogyakarta. Perangkat lunak yang digunakan untuk melakukan analisis adalah Eviews 8. Hasil penelitian menunjukkan bahwa variabel jumlah wisatawan berpengaruh positif dan tidak signifikan, variabel jumlah obyek wisata tidak berpengaruh signifikan dan variabel jumlah hotel berpengaruh positif dan signifikan terhadap pendapatan asli daerah sektor pariwisata di Daerah Istimewa Yogyakarta.
\end{abstract}

Kata Kunci: Jumlah wisatawan, Jumlah obyek wisata, jumlah hotel dan pendapatan asli daerah.

Berdasarkan Undang-Undang Nomor 32 Tahun 2004, menyatakan bahwa Otonomi Daerah pada dasarnya adalah hak, wewenang dan kewajiban daerah untuk mengatur dan mengurus rumah tangganya sendiri. Otonomi Daerah bertujuan untuk memaksimalkan pembangunan daerah. meningkatkan pertumbuhan ekonomi, mengurangi kesenjangan, serta meningkatkan layanan public Andirfa (2009) dalam widiana dan Sudiana (2015). Pembangunan ekonomi suatu Negara dapat dilakukan dengan cara meningkatkan pertumbuhan ekonominya. Kegiatan peningkatan pertumbuhan perekonomian ini terkait dengan peningkatan perekonomian daerah termasuk meningkatkan Pendapatan Asli Daerah (PAD). Di samping pengelolaan terhadap sumber $P A D$, suatu daerah juga harus kreatif untuk mengelola sumber-sumber PAD yang dimiliki, sehingga dengan adanya pengelolaan yang lebih serius terhadap sumber-sumber PAD maka akan semakin banyak pula pendapatan yang akan dipergunakan untuk membangun suatu daerah (Elizabeth et al, 2012).

Melihat potensi yang dimiliki Daerah Istimewa Yogyakarta dengan diiringi perkembangan teknologi yang berkembang pesat pada saat ini maka dapat diprediksi bahwa wisata di DIY akan terus mengalami peningkatan kualitas dan mendorong perekonomian sekitar Berkembangnya jumlah Wisatawan, Jumlah Objek Wisata serta Jumlah 
Hotel yang ada di DIY. Hal tesebut diharapkan dapat berdampak yang posistif terhadap peningkatan jumlah Pendapatan Asli Daerah (PAD) yang diterima oleh Daerah Istimewa Yogyakarta.

Pendapatan Asli Daerah (PAD) menurut Undang-Undang No. 33 Tahun 2004 yang dimaksud dengan Pendapatan Asli Daerah atau yang selanjutnya disebut PAD adalah pendapatan yang diperoleh daerah yang dipungut berdasarkan Peraturan Daerah sesuai dengan peraturan perundang-undangan. Pendapatan Asli Daerah merupakan salah satu indikator dari kemandirian otonomi daerah dalam menggali potensi untuk meningkatkan sumber-sumber penerimaan. Semakin besar pendapatan asli daerah maka semakin dinilai mandiri daerah dalam mengambil keputusan dan kebijakan pembangunan

Pariwisata menurut Undang-Undang No.10 Tahun 2009 tentang kepariwisataan, pariwisata adalah berbagai macam kegiatan wisata dan didukung berbagai fasilitas serta layanan yang disediakan oleh masyarakat, pengusaha, pemerintah daerah. Sedangkan menurut (Spilane, 1897 dalam Putri 2020 ) pariwiata adalah perjalanan dari suatu tempat ketempat yang lain, bersifat sementara dilakukan secara perorangan maupun kelompok sebagai usaha untuk mencari keseimbangan dan keserasian dan kebahagiaan dengan lingkungan hidup dalam dimensi sosial budaya alam dan ilmu.

Jumlah wisatawan, Wisatawan menurut Undang-Undang 10 tahun 2009 dalah orang-orang yang melakukan kegiatan wisata. Sedangkan untuk jumlah wisatawa adalah banyaknya wisatawan yang diukur berdasarkan kuantitas Untuk jenis wisatawan dibagi menjadi dua yaitu berdasarkan dari mana datang atau asal Negara, meliputi wisatawan domestik dan wisatawan mancanegara. menurut penelitian dari Jerfi Tri Aprilianto dan Susilo ( 2016), dengan hasil penelitian yang menyatakan bahwa jumlah wisatawan berpengaruh positif dan signifikan terhadap pendapatan asli daerah karena semakin banyak wisatawan yang datang maka konsumsi terhadap produk pariwisata akan semakin meningkat, meningkatnya konsumsi tersebut akan meningkatkan kontribusi sektor pariwisata dan memperbesar pendapatan asli daerah. Hal tersebut juga didukung oleh penelitian yang dilakukan oleh Yulie Suryani ( 2017) dan Melinda Eka Putri (2020) yang menyatakan hasil yang sama bahwa variabel jumlah wisatawan berpengaruh positif dan signifikan terhadap pendapatan asli daerah kota pariaman.

Objek Wisata, Menurut SK. MENPARPOSTEL No.: KM. 98/ PW. 102/ MPPT-87 objek wisata adalah semua tempat atau keadaan suatu alam yang memiliki sumber daya wisata yang kemudian dilakukan pembangunan dan dikembangkan sehingga mempunyai daya tarik tersendiri dan diusahakan sebagai tempat yang menarik untuk dikunjungi wisatawan Banyaknya objek wisata yang ada di suatu daerah tentu dengan sendirinya akan menarik wisatawan baik yang dari manca negara maupun wisatawan nusantara untuk datang ke daerah tersebut, tentu saja kedatangan wisatawan akan mendatangkan penerimaan terhadap daerah 
tersebut, dengan sendirinya akan memberikan pengaruh terhadap pendapatan asli daerah (Ulhusna Rani, 2017). Sedangkan menurut (Ridwan, 2012 dalam Karmansyah dan Ahmad Firman, 2020) mengemukakan bahwa objek wisata adalah segala sesuatu yang memiliki ciri khas atau keunikan, keindahan serta nilai berupa keanekaragaman kekayaan alam, budaya, adat istiadat dan hasil buatan manusia yang menjadi sasaran dan destinasi kunjungan wisatawan.

Jumlah Hotel, Hotel merupakan suatu bangunan yang berupa kamar-kamar dan dilengkapi dengan pelayaan makan dan minum, serta hiburan dan fasilitas penunjang hotel lainnya (BPS DIY, 2017) Fungsi hotel bukan hanya sebagai tempat penginapan saat berwisata ke suatu daerah tetapi hotel juga dapat digunakan untuk pertemuan dalam hal urusan pekerjakan bahkan saat ini fungsi hotel juga digunakan untuk seminar, menjalankan kegiatan bisnis, ataupun hanya untuk mencari ketenangan.

Penelitian Melinda Eka Putri (2020) yang menyatakan bahwa jumlah hotel pengaruh positif dan signifikan terhadap pendapatan asli daerah karena perhotelan memiliki peran dalam pergerakan pembangunan daerah, dan perlu sekali untuk dikembangkan secara baik dan optimal, sehingga dapat meningkatkan pendapatan masyarakat, PAD, penyerapan tenaga kerja serta peluasan sektor usaha. Penelitian ini bertujuan untuk menganalisis pengaruh Jumlah Wisatawan, Jumlah Objek Wisata dan Jumlah Hotel terhadap pendapatan asli daerah sektor pariwisata di daerah istimewa Yogyakarta.

\section{METODE}

Penelitian ini merupakan jenis penelitian kuantitatif. variabel yang terlibat dalam penelitian ini adalah Pendapatan Asli Daerah sebagai variabel terikat dan jumlah wisatawan, jumlah obyek wisata dan jumlah hotel sebagai variabel bebas. Populasi penelitian ini adalah kota/kabupaten di Daerah Istimewa Yogyakarta pada tahun 2012-2018, dengan sampel Kab.Bantul, Kab Gunung Kidul, Kab Kulon Progo, Kab Sleman dan Kota Yogyakarta.

Jenis data yang digunakan adalah data sekunder yang diambil dengan metode dokumenter. Data sekunder didapatkan melalui BPS DIY, literature, studi pustaka dan penelitian terdahulu yang relevan dan juga dari Dinas Pariwisata dan kebudayaan DIY. . didalam penelitian ini menggunakan analisis regresi data panel yang merupakan kombinasi anatara data cros section dengan data time series, untuk alat pengolahan data menggunakan Eviews 8 . 


\section{Metode Analisis Data}

1. Analisis Statistik Deskriptif

Analisis statistik deskriptif merupakan suatu analisis yang menggambarkan deskripsi dari data variabel yang digunakan dalam penelitian yang dilihat dari nilai rata-rata (mean), standar deviasi, varian, maksimum, minimum, sum, range, kurtosis dan skewness (Ghozali,2013)

2. Estimasi Regresi Data Panel

Untuk mengistimasi bentuk dari regresi data panel menurut (Widarjono, 2009) terdapat tiga macam pendekatan yang dapat digunakan diantaranya: common effect model, fixed effect model dan random effect model. Untuk memilih model yang paling tepat dapat menggunakan beberapa pengujian:

a. Uji Chow

Chow test merupakan pegujian untuk menentukan model yang paling tepat untuk digunakan dalam mengestimasi data panel, apakah model common effect atau fixed effect dengan cara melihat nilai Prob dan Chi-square tabel.

Apabila hasil:

$\mathrm{HO}$ : Pilih common effect model ( Prob > $0.05 \%$ )

$\mathrm{H} 1$ : Pilih fixed effect model ( Prob $<0.05 \%$ )

b. Uji Hausman

Hausman test atau uji hausman adalah suatu pengujian statistik untuk memilih apakah model fixed effect atau random effect yang paling tepat digunakan dalam mengestimasi data panel dengan melihat nilai Prob dan Chi-square tabel .

Apabila hasil:

$\mathrm{HO}$ : Pilih random effect model ( Prob > $0.05 \%$ )

$\mathrm{H} 1$ : Pilih fixed effect model ( Prob $<0.05$

c. Uji Langrange Multiplier Test (LM)

Adalah pengujian statistic untuk memilih apakah model random effect atau fixed effect yang paling tepat digunkan dalam mengestimasi data panel. Uji ini dilakukan hanya ketika hasil dari uji chow dan uji hausman menghasilakan model yang berbeda dapat dilihat pada nilai Breusch-pagan kolom both.

Apabila hasil:

HO: pilih Random effect model (Prob < $0.05 \%$ )

H1:pilih common effect model (Prob > 0.05\%)

Dengan dilakukannya metode analisis data diatas, maka didapatkan model regresi data panel sebagai berikut

PADit $=\alpha+\beta 1(J W)$ it $+\beta 2(J O W) i t+\beta 3(J H) i t+$ eit 
Dimana:

PADit : Pendapatan Asli Daerah (PAD)

a : Konstanta

$\beta 1,2,3 \quad$ : Koefisien Variabel Independen

JWit :Jumlah Wisatawan

JOWit :Jumlah Objek Wisata

JHit : Jumlah Hotel

Eit :Error

3. Pengujian Hipotesis

a. Uji Signifikansi Simpultan (Uji F)

Uji $F$ digunakan untuk mengetahui signifikansi atau tidak signifikansi antara variabel independen dan variabel dependen secara menyeluruh

1) $\mathrm{HO}: \beta 1=\beta 2=\beta 3=\beta 4=0$ menunjukan semua variabel independen ( jumlah wisatawan, jumlah objek wisata dan jumlah hotel) tidak dapat mempengaruhi variabel dependen pendapatan asli daerah) secara bersama-sama dalam model.

2) $\mathrm{H} 1: \beta 1 \neq \beta 2 \neq \beta 3 \neq \beta 4=0$ menunjukan semua variabel independen ( jumlah wisatawan, jumlah objek wisata dan jumlah hotel) tidak dapat mempengaruhi variabel dependen pendapatan asli daerah) secara bersama-sama dalam model.

Dengan kriteria Jika besarya nilai $\mathrm{F}$ hitung $>\mathrm{F}$ tabel, maka $\mathrm{HO}$ ditolak dan $\mathrm{H} 1$ diterima

b. Uji Signifikansi Parameter Individual (Uji T)

Gujarati (2001) mengemukakan pendapat bahwa Uji $t$ statistik dilakukan untuk menguji pengaruh variabel bebas terhadap variabel terikat secara individual dan menganggap variabel bebas yang lain konstan. Untuk Hipotesis yang digunakan dalam pengujian ini adalah:

1) $\mathrm{HO}: \beta=0$, menunjukan variabel independen ( jumlah wisatawan, jumlah objek wisata dan jumlah hotel) tidak berpengaruh secara nyata terhadap variabel dependen ( pendapatan asli daerah) .

2) $\mathrm{H} 1: \beta>0$ menunjukan variabel independen ( jumlah wisatawan, jumlah objek wisata dan jumlah hotel) berpengaruh positif secara nyata terhadap variabel dependen ( pendapatan asli daerah) .

c. Uji Koefisien Determinan (R2)

Menurut (Gujarati, 2003) Uji Koefisien determinasi (R2) digunakan untuk mengetahui sampai seberapa besar persentase variasi dalam variabel terikat pada model dapat diterangkan oleh variabel bebasnya. Nilai R2 berkisar antara $0<$ $\mathrm{R} 2<1$ 


\section{HASIL}

Berdasarkan dari hasil analisis regresi data panel diatas yang dilakukan dengan menggunakan program Eviews 8 untuk menentukan model common effect, Fixed effect atau random effect yang terbaik untuk digunakan, maka diperoleh hasil penelitian tiap uji sebagai berikut:

Analisis Statistik Deskriptive

Tabel 1. Hasil Analisis Statistik Deskriptive

\begin{tabular}{|c|c|c|c|c|}
\hline \multicolumn{5}{|l|}{$\begin{array}{l}\text { Date: } 12 / 25 / 20 \\
\text { Time: } 10: 01 \\
\text { Sample: } 135\end{array}$} \\
\hline & PAD & JW & JOW & JH \\
\hline Mean & $5.99 \mathrm{E}+10$ & 3823485. & 28.42857 & 248.8286 \\
\hline Median & $2.58 \mathrm{E}+10$ & 3654145. & 23.00000 & 262.0000 \\
\hline Maximum & $2.18 \mathrm{E}+11$ & 9141150. & 70.00000 & 624.0000 \\
\hline Minimum & $2.11 \mathrm{E}+09$ & 596529.0 & 8.000000 & 24.00000 \\
\hline Std. Dev. & $6.45 \mathrm{E}+10$ & 2238915 . & 17.95138 & 179.6782 \\
\hline Skewness & 1.025892 & 0.590488 & 0.970657 & 0.110408 \\
\hline Kurtosis & 2.760723 & 2.811140 & 2.788502 & 1.815483 \\
\hline Jarque-Bera & 6.222809 & 2.085960 & 5.561259 & 2.117266 \\
\hline Probability & 0.044538 & 0.352403 & 0.061999 & 0.346930 \\
\hline Sum & $2.10 \mathrm{E}+12$ & $1.34 \mathrm{E}+08$ & 995.0000 & 8709.000 \\
\hline Sum Sq. Dev. & $1.41 \mathrm{E}+23$ & $1.70 \mathrm{E}+14$ & 10956.57 & 1097665. \\
\hline Observations & 35 & 35 & 35 & 35 \\
\hline
\end{tabular}

Sumber: pengolahan data dengan Eviews 8

Berdasarkan tabel 1 dapat diketahui bahwa Pendapatan asli daerah (PAD) memiliki nilai rata-rata selama tahun 2012-2018 adalah sebesar 59.940.418.855 dengan nilai $R^{2}$ yaitu 64.461.479.844.

Analisis Hasil Uji Pemilihan Model:

1. Hasil Uji Chow

Berikut adalah hasil regresi untuk uji chow:

Tabel 2. Hasil Uji Chow

\begin{tabular}{|lrrr|}
\hline Effects Test & Statistic & d.f. & Prob. \\
\hline \hline Cross-section F & 1.187712 & $(6,25)$ & 0.3447 \\
Cross-section Chi-square & 8.777941 & 6 & 0.1865 \\
\hline
\end{tabular}

Sumber: Hasil Pengolahan Data dengan Eviews 8

Berdasarkan tabel 2 diatas, maka dapat diketahui nilai dari probabilitas sebesar $(0,1865>0,05)$. Maka dengan itu dapat disimpulkan model yang paling tepat digunakan adalah common effect model.

2. Hasil Uji Hausman

Berikut adalah hasil regresi untuk uji hausman.

Tabel 3. Hasil Uji Hausman

\begin{tabular}{|c|c|c|c|}
\hline Test Summary & $\begin{array}{l}\text { Chi-Sq. } \\
\text { Statistic }\end{array}$ & Chi-Sq. d.f. & Prob. \\
\hline
\end{tabular}


\begin{tabular}{llll|} 
Cross-section random & 7.010139 & 3 & 0.0716 \\
\hline
\end{tabular}

Sumber: Hasil Pengolahan Data dengan Eviews 8

Berdasarkan Tabel 3 diatas diperoleh nilai probabilitas sebesar $0.0716>0,05$ maka dengan itu H0 diterima dan H1 ditolak. Dan dengan demikian, maka model yang digunakan adalah random effect model.

3. Hasil Uji Lagrange Multiplier (LM)

Uji yang membandingkan antara Random Effect Model dengan Common Effect Model.

Tabel 4. Hasil Uji Lagrange Multiplier

\begin{tabular}{|lccc|}
\hline $\begin{array}{l}\text { Null (no rand. effect) } \\
\text { Alternative }\end{array}$ & $\begin{array}{c}\text { Cross-section } \\
\text { One-sided }\end{array}$ & $\begin{array}{c}\text { Period } \\
\text { One-sided }\end{array}$ & Both \\
\hline \hline Breusch-Pagan & $\begin{array}{l}0.436514 \\
(0.5088)\end{array}$ & $\begin{array}{l}1.827300 \\
(0.1764)\end{array}$ & $\begin{array}{l}2.263814 \\
(0.1324)\end{array}$ \\
\hline
\end{tabular}

Sumber: Hasil Pengolahan Data dengan Eviews 8

Berdasarkan Tabel 4. diperoleh nilai Brusch-pagan kolom 3 (both) sebesar 0,1324>0,05 maka H0 ditolak yang berarti estimasi yang tepat untuk regresi data panel adalah model common effect.

Hasil dari uji pemilihan model terpilihlah estimasi Common Effect Model . dengan rincian satu pengujian untuk menggunakan Randm Effect Model ( Uji Hausman ), dan dua pengujian yang lainnya menyarankan untuk menggunakan Common Effect Model (Uji Chow dan Uji LM).

Analisis Hasil Uji Regresi Data Panel

Dengan menggunakan uji yang terpilih yaitu Common Effect Model, maka dari itu didapatkan bentuk persamaan regresi data panel sebagai berikut dengan menggunakan nilai alpha 0.05 .

PAD = -3.070.130.99 + 2599.992 JW - 5.4439230 JOW + 2.7542043 JH

Tabel 5. Hasil Uji Regresi Data Panel Common Effect Model

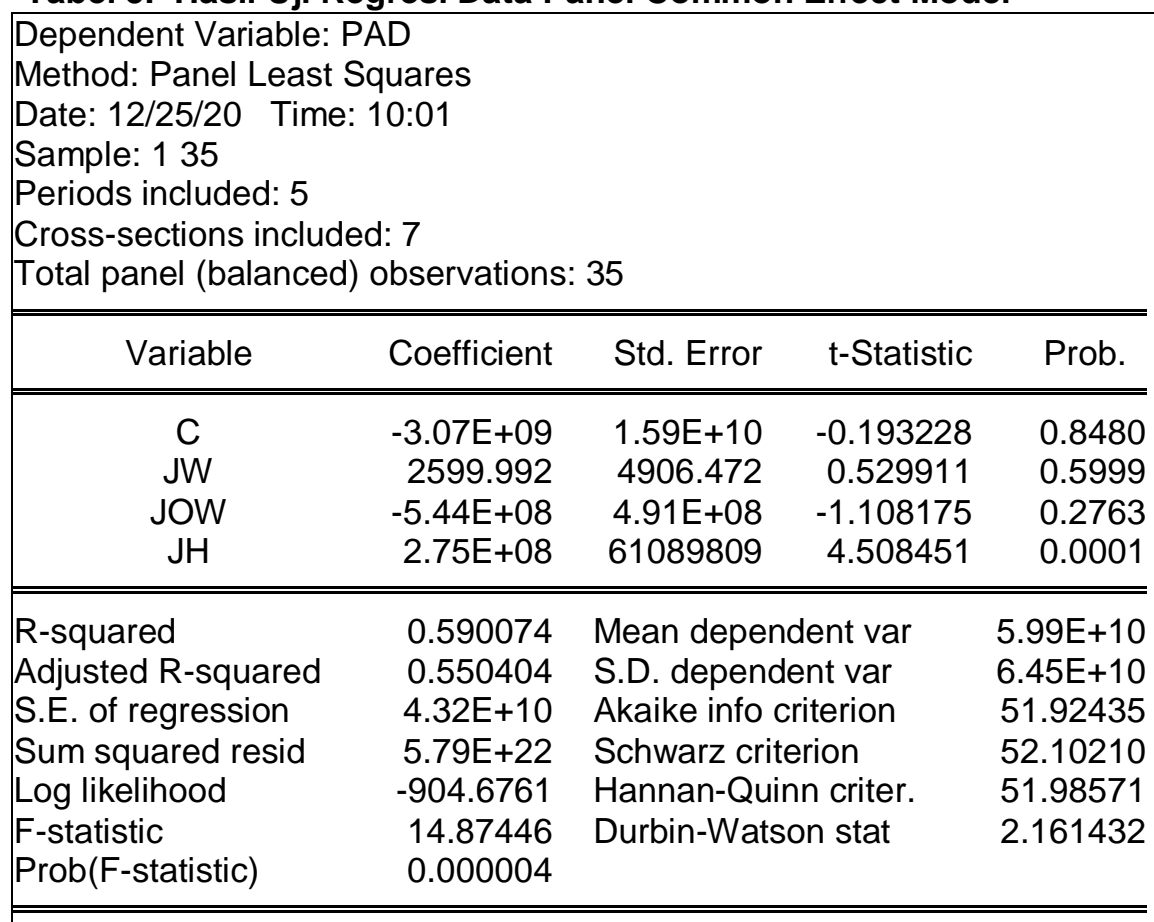


Sumber: Hasil Pengolahan Data dengan Eviews 8

\section{Pengujian Hipotesis}

a. Uji Simpultan (Uji F)

Dari hasil regresi diperoleh nilai F-statistik sebesar 14.87446 dengan probabilitas $0.000004<0,05 \%$, sehingga dapat disimpulkan bahwa variabel jumlah wisatawan, jumlah objek wisata dan jumlah hotel bersama-sama mempengaruhi variabel Pendapatan Asli Daerah sektor pariwisata.

b. Uji Parsial (Uji t)

Berdasarkan hasil regresi diatas diperoleh informasi sebagai berikut:

1) Jumlah wisatawan $(0.5999>0.05)$, yang artinya bahwa jumlah wisatawan tidak berpengaruh secara signifikan terhadap pendapatan asli daerah berarti tidak ada perbedaan pendapatan.

2) Jumlah Objek Wisata $(0.2763>0.05)$, yang artinya bahwa jumlah wisatawan tidak berpegaruh secara signifikan terhadap pendapatan asli daerah berarti tidak ada perubahan jumlah pendapatan asli daerah yang disebabkan dengan bertambahnya jumlah objek wisata jika tidak didukung kualitas objek wisata untuk menarik simpati.

3) Jumlah Hotel $(0.0001<0.05)$, yang artinya jumlah hotel berpengaruh positif dan signifikan terhadap pendapatan asli daerah.

c. Koefisien Determinasi

koefisien determinasi ( $R$ square $)=0.590074$ artinya variabel bebas bersama-sama mempengaruhi variabel tidak bebas sebesar $59 \%$ sisanya sebesar $41 \%$ dpengaruhi oleh variabel lain yang tidak terdeteksi dalam penelitian ini.

\section{PEMBAHASAN}

a. Pengaruh Jumlah Wisatawan Terhadap Pendapatan Asli Daerah (PAD)

Bahwa nilai dari koefisiensi regresi variabel jumlah wisatawan sebesar 2599.992 yang artinya jumlah wisatawan dan pendapatan asli daerah bersifat searah atau bersifat positif. Dalam artian setiap peningkatan jumlah wisatawan sebanyak 1 orang diharapkan akan meningkatkan jumlah pendapatan asli daerah sebesar Rp 25.999.92.

b. Pengaruh Jumlah Objek wisata Terhadap Pendapatan Asli Daerah (PAD)

Bahwa nilai dari koefisiensi regresi variabel jumlah objek wisata sebesar -5.4439230 Maka jumlah wisatawan tidak memiliki 
pengaruhnya terhadap pendapatan asli daerah dikarenakan perbaikan kwantitas objek wisata yang tidak diimbangi dengan perbaikan kwalitas dari objek wisata tidak akan menarik minat dari wisatawan maka dari itu tidak dapat mempengaruhi pendapatan asli daerah.

c. Pengaruh Jumlah Hotel Terhadap Pendapatan Asli Daerah (Pad)

Bahwa nilai dari koefisiensi regresi variabel jumlah hotel sebesar 2.7542043. yang artinya jumlah wisatawan dan pendapatan asli daerah bersifat searah atau bersifat positif. Dalam artian setiap peningkatan jumlah wisatawan sebanyak 1 orang diharapkan akan meningkatkan jumlah pendapatan asli daerah sebesar Rp 257.542.043.

\section{KESIMPULAN}

1. Model estimasi regresi data panel yang baik untuk digunakan pada penelitian ini adalah model common effect dimana hasil nilai Adjusted R-squared menunjukan angka 0.55 nilai tersebut menunjukan bahwa variabel-variabel independen meliputi Jumlah Wisatawan (JW), Jumlah Objek Wisata (JOW) dan Jumlah Hotel (JH) terhadap Pendapatan Asli Daerah (PAD) di Provinsi Daerah Istimewa Yogyakarta mampu menjelaskan Variabel-variabel depeden Pendapatan Asli Daerah sebesar 59\% dan sisanya dijelaskan oleh variabel lain diluar model.

2. Variabel Jumlah Wisatawan Di Provinsi Daerah Istimewa Yogyakarta dari hasil analisis diperoleh bahwa jumlah wisatawan berpengaruh positif dan tidak signifikan terhadap pendapatan asli daerah dengan nilai probabilitas 0,5999.

3. Variabel Jumlah Objek Wisata Di Provinsi Daerah Istimewa Yogyakarta dari hasil analisis diperoleh bahwa jumlah wisatawan tidak berpengaruh dan tidak signifikan terhadap pendapatan asli daerah dengan nilai probabilitas 0,2763.

4. Variabel Jumlah Hotel Di Provinsi Daerah Istimewa Yogyakarta dari hasil analisis diperoleh bahwa jumlah hotel berpengaruh positif dan signifikan terhadap pendapatan asli daerah dengan nilai probabilitas 0,0001 .

\section{DAFTAR PUSTAKA}

Aprilianto, Jefri Tri Dan Susilo. 2016/2017. Analisis Peran Sektor Pariwist Terhadap Pendapatan Asli Daerah Pada Kabupaten Dan Kota Di Jawa Timur. Jurnal IImian Mahasiswa FEB, 5(1)

Badan Pusat Statistika.. DIY Dalam Angka . Yogyakarta: Badan Pusat Statistik.

Dinas Pariwisata Daerah Istimewa Yogyakarta. Statistik kepariwisataan. Yogyakarta

Gujarati, D. (2001). Ekonometrika Dasar. Jakarta: Erlangga.

Gujarati, D. (2003). Ekonometri Dasar. (S. Zain, Ed.). Jakarta: Erlangga. 
Karmansyah Dan Ahmad Firman. 2020. Kontribusi Wisata Hutan Mangrove Tongke-Tongke Terhadap Pendapatan Asli Daerah Sektor Pariwisata Kabupaten Sinjai. Akmen Jurnal IImiah, 17(1), 163-171

Manurung ET, dkk. Perbandingan Kontribusi Industri Pariwisata Dalam Meningkatkan Pendapatan Asli Daerah Di Kabupaten Bandung Dan Jember, Universitas Katolik Parahyangan, Bandung Jawa Barat

Putri, ME. 2020. Peran Sektor Pariwisata Terhadap Pendapatan Asli Daerah (Studin Kasus Kabupaten/Kota Provinsi Sulawesi Selatan) Tahun 2014-2018. Jurnal IImiah Mahasiswa FEB, 8(2)

Rani FP, dkk. 2018. Pariwisata Pustaka: Destinasi Dan Motivasi Wisata Di Pusaka Saujana Imogiri Yogyakarta. Jurnal Planologi, 15(2)

SK. MENPARPOSTEL No.: KM. 98/ PW. 102/ MPPT-87. Tentang Pengertian Objek Wisata

Suryani,Yuli. 2017. Aktivitas Sektor Pariwisata Terhadap Pendapatan Asli Daerah (PAD) Di Kota Pariaman. Jurnal Menara IImu, 11(76), 147154

UU. No.34. 1990 Tentang Kepariwisataan

UU No. 34 . 2000 tentang Perubahan atas Undang-undang Republik Indonesia No.18 tahun 1997 tentang Pajak dan Retribusi Daerah.

UU No.33. 2004. Tentang Perimbangan Keuangan Antara Pemerintah Pusat Dan Pemerintah Daerah.

UU No. 10. 2009. Tentang Kepariwisataan

Widarjono, Agus. 2009. Ekonometrika Aplikasi Dan Teori Untuk Ekonomi Dan Bisnis. Yogyakarta: Ekonisia.

Widiana INW dan Sudiana IK. 2015. Pengaruh Jumlah Kunjungan Wisatawan, Pajak Hotel Restoran Dan Pendapatan Asli Daerah Terhadap Belanja Modal Kabupaten/Kota Di Provinsi Bali. E-Jurnal Ekonomi Pembangunan Universitas Udayana, 4(11) 